\title{
Imperative Sentences in Java Ngoko in North Sumatra
}

DOI: https://doi.org/10.47175/rielsj.v2i3.305

\author{
1,2 University of Prima \\ Indonesia \\ ${ }^{1}$ nandadwiastri75@gmail.com, \\ ªndiepard21@gmail.com
}

| Nanda Dwi Astri ${ }^{1}$ | Oktaviandi Bertua Pardede ${ }^{2}$ |

\begin{abstract}
This study uses a qualitative method. Qualitative method is a method that uses descriptive methods to describe data by describing related events both in writing and verbally. The research procedure consists of three stages, namely the stage of data collection, data analysis, and presentation of data analysis. The method used in data collection is the method of observing. The technique used in data collection is a free-to-conversation listening technique by observing and recording data in the form of imperative sentences in the Ngoko Javanese language in North Sumatra. The purpose of this study is to increase knowledge and increase understanding of language command sentences Java Ngoko in North Sumatra. The source of the data in this research is the people in Bandar Tengah village, Bandar Khalipa $h$, North Sumatra as speakers of the Javanese Ngoko language. Based on the results of the study, imperative sentences in Javanese. Ngoko contain the intent to command, prohibit, invite, order repeatedly, invite, request, be angry, and ask for help.

KEYWORDS

imperative sentence; Javanese Nqoko; North Sumatra
\end{abstract}

\section{INTRODUCTION}

Language is a cognitive system that is part of normal post anything else to the mental or psychological structure. Language in general can be in the form of words, phrases, clauses, sentences and discourses. Sentence is a language utterance that is spoken directly and indirectly. As speakers, as social beings, humans cannot live alone without the help of others. Therefore, humans are no longer individuals, but social communities. One of them is social life, language is a means of communicating with our interlocutors, and everything people do in their speech is influenced by situations and conditions. In such situations and conditions, it can be influenced by various types of language forms and regional language abilities. For example, the Toba Javanese Batak language, the Minang Kabau language, or the Nias language. Because we know each language, the sound and meaning of the words will be different. Therefore, of course, humans need language as a tool for human interaction. The importance of language in social life. According to Keraf (1997:1), language is a means of communication between community members in the form of sound symbols produced by human speech tools.

According to Bolinger (1981), language has a phoneme system composed of unique characteristics of sound, morpheme system and grammar. The meaning of the expression language must be connected with the outside world. The outside world refers to the world outside the language, including the world within the language user. In this sense, the world is called reality. According to Felicia (2001:1), language is a means of everyday communication, including spoken and written language. Based on the above understanding, it can be concluded that language is a means of communication with community members 
in the form of sound symbols produced by the human voice. The Indonesian nation is one of the countries in the world that has a variety of languages and ethnicities spread throughout the country. Each region in Indonesia has a different regional language and culture. In everyday life, many people use Indonesian and regional languages as a means of communication (Rahmawati, Asrul, N., \& Daulay, I. K. 2021).

In this study, the Ngoko Javanese language in North Sumatra will be discussed. The Javanese language is still used by the Javanese people in the village of Bandar Tengah, Bandar Khalipah District, North Sumatra as their daily language. This proves that the existence of the Javanese language is so high. Even though it is no longer in the area of origin, the Javanese language continues to develop even outside the area.

Imperative sentences in this study are sentences that are commanding or giving commands and are mandatory. According to Cook (1971:31), a command sentence is a response sentence designed to bring about action or behavior. Meanwhile, Kridalaksana (1993:31) suggests that imperative sentences are sentences that contain imperative intonation in written texts usually marked with a dot (.) or an exclamation mark (!).

Imperative sentences are sentences that contain commands, suggestions, requirements, and expectations that the imperative sentence is a sentence that is formed to provoke a response in the form of an action or deed. Meanwhile, Kridalaksana (1993:31) mentions that command sentences with the term imperative sentences, namely sentences containing imperative intonation in written form are usually marked with a period (.) or exclamation (!). Imperative sentences are sentences that contain the intent of commanding, advising, requesting, and hoping. Therefore, it can be concluded that an imperative sentence is a sentence that contains elements of a command or invitation sentence. The existence of imperative sentences in the Javanese Ngoko dialect of North Sumatra is used to ask the speech partner to do something. Lack of attention to the use of imperative sentences in Javanese Ngoko so that they are less able to apply them properly. People are less able to convey an explanation of how to apply imperative sentences to other audiences. The speaker expects a reaction from the interlocutor. Therefore, imperative sentences in Javanese Ngoko Javanese have various types of markers that are used to see that the sentence is an imperative sentence. This study uses imperative sentences in the Javanese Ngoko language by people in Bandar Tengah village, Bandar Khalipah sub-district, North Sumatra while doing social activities.

This research is different from previous research, because the focus of the research is the Javanese Ngoko language in the village of Bandar Tengah, Bandar Khalipah District, North Sumatra which still continues to maintain its existence. Every language in the world has unique characteristics and not all of its people can maintain its existence, especially if the community has left their area of origin. This is the background of researchers interested in examining the imperative sentences of Ngoko Javanese language by speakers in Bandar Tengah village, Bandar Khalipah sub-district, North Sumatra. The researcher wants to reveal the uniqueness of Javanese imperative sentence in the village which still maintains the existence of Javanese language even though it has left its native area. Therefore, the researcher studied Imperative Sentences in Ngoko Javanese in North Sumatra.

Based on the above background, the formulation of the problem in this study is (1) What are the forms of imperative sentences in Ngoko Javanese in North Sumatra? And (2) What is the meaning of the sentence Imperative in Javanese Ngoko in North Sumatra?. In order to reduce the scope of research, it is necessary to focus on the limitations of the problem in research and discussion so that it is more concentrated. Therefore, the limitation of this research is imperative sentences in Ngoko Javanese in North Sumatra. The benefits of the results of this study are in the form of a description of imperative sentences in Ngoko 
Javanese based on command markers. This description covers the types of imperative sentences in Ngoko Javanese. Theoretically, this research provides input in the field of syntactic and pragmatic studies. In the field of syntactic studies, the description of imperative sentences in Ngoko Javanese strengthens the theory that sentence types are determined by intonation patterns and their markers. In the field of pragmatic studies, the description of the intent contained in imperative sentences confirms the theory that the use of sentences in communication is motivated by the speaker's intentions. The practical benefit of the results of this study is to provide input in the preparation of Javanese Grammar.

\section{RESEARCH METHODS}

This research was conducted through three stages, the first stage of data collection, the second stage of data analysis, and in third stage is the presentation of the results of the data analysis. The following will describe each stage in this research.

\section{Data Collection Techniques}

The object of this research is the imperative sentence in Javanese ngoko. The object of this research is in the data in the form of sentences. Data were obtained from oral sources, namely Javanese speakers in North Sumatra. The data collected is data in the form of sentences, which contain imperative sentences in Javanese ngoko. Data was collected using the look method. According Sudaryanyo (1993:132-133), this method consider is the method of data collection is done by way of observing and listening direct use of language. The technique used in the data collection stage is a non-participant technique or a free-to-conversation listening technique by observing and recording data in the form of imperative sentences in Javanese ngoko by speakers in North Sumatra. The data that has been collected is classified based on its category and type.

\section{Data Analysis Method}

At the data analysis technique stage, the data is classified, then analyzed using the equivalent method. According to Sudaryanto (1993:13-14), the equivalent method is a method whose determinants are outside, independent of, and do not become part of the language in question. The determining tool is the reality shown by language or language referents. Because imperative sentences in Javanese ngoko involve the intonation of each sentence, the equivalent method is seen as the right method.

The equivalent method is used to analyze whether a sentence is an imperative sentence or not. If the sentence is in accordance with the function of the imperative sentence, then the sentence can be considered as an imperative sentence.

Yem, umbeh wedang iki ndhisik!.

'Yem, drink this water first!'

This sentence is an imperative sentence because it has the intention to imparative, told hearer (Yem) to take action that is ngumbeh wedang iki dhisik!. 'Drink this water first! '. In the matching method, discriminating power is used as a differentiator for reactions and audibility levels. As for the relationship with the speech partner, it can be distinguished various reactions from him in addition to the level of audibility by him. Example:

Paijo , jupukna sego iku!.

'Paijo, get that rice !'. 
The sentence is an imperative sentence that has a reaction, namely the speech partner (Paijo) to act according to what is said by the speaker. In addition, the sentence has a level of sounding loud and stressed.

In this study, the method was also used, which is a method in which the determine tool is part of the language itself (Sudaryanto, 1993:13-15). The technique used in this method is the mark reading technique and the direct element technique. Mark reading technique is used to show the essence of imperative sentences in Javanese ngoko. In this study, the BM technique was applied to see the imperative sentence in Javanese ngoko syntactically. It can be seen from the following example.

$$
\begin{array}{ccc}
\frac{\text { tri, }}{S} & \frac{\text { crap }}{P} & \frac{\text { medicine !. }}{O} \\
\text { Tri, } & \text { drink } & \text { drug!'. }
\end{array}
$$

This sentence is an imperative sentence, because it is a type of imperative sentence that is unmarked and has a sentence structure, namely SPO. The direct element division technique is used to divide imperative sentences in Javanese ngoko based on their type and meaning. For example:

\section{Paijo , jupukna sego iku !. 'Paijo, get that rice '!}

It includes the type of imperative sentence marked with a verb - $n a$, and belongs to the type of imperative sentence which has the intention to rule.

\section{Presentation of Data Analysis Results}

Data analysis in this study is presented using informal methods and formal methods, with using the usual words are words that are not words denotative and connotative nature. The formal method, which uses signs, symbols, abbreviations and the like. The signs used include (*) Sudaryanto (1993:145).

\section{RESULTS AND DISCUSSION}

Imperative sentences in Javanese ngoko have several forms and purposes. ie First, max ud to command. Second, the intent to prohibit. Third, the intention to invite. Fourth, the intention to order repeatedly. Fifth, the intention to invite. Sixth, the intent of the request. Seventh, mean anger. Eighth, the purpose of asking for help. In this chapter, we will discuss the meaning of imperative sentences in Javanese ngoko in North Sumatera.

\section{Forms of Imperative Sentences Containing an Order}

The form of imperative sentences that contain the meaning of an order is an imperative sentence which is marked by the presence of a verb ending in $-e$ and a verb ending in -no. Example:

(1) Yanti.golekke selopku!

'Yanti, find my sandals!'

(2) Yanti, Iwan juphukno segho!

'Yanti, Iwan in fetch rice!'

The purpose of sentence (1) above is to ask someone named Yanti to find sandals. As for the purpose of sentence (2) is to order someone named Yanti to get rice for Iwan. 


\section{Forms of Imperative Sentences Containing Prohibition}

The form of an imperative sentence which contains the intent of prohibition is an imperative sentence which is marked by the presence of the Ojo verb ' Don't'. This imperative sentence means to prohibit doing something. Example:

(3) Ojo diguwak endas weduse!

'Don't throw away the goat's head!'

(4) Segho Iwan ojo dipangan, Yanti!

'Don't eat Iwan's rice, Yanti!'

In sentence t (3) it contains the intent to forbid someone to throw away the head of a goat. Sentence (4) contains the intent to forbid Yanti from eating Iwan's rice.

\section{Forms of Imperative Sentences Containing Invitation}

The form of an imperative sentence that contains an invitation is an imperative which is marked by the presence of the verb Ayok 'let '. Example:

(5) Ayok lungo nang langgar!

' Let's go to the mosque!'

(6) Yen ngono ayok kita goleki, bapakmu uwes ngamok iku! 'Then let 's go find, your father is already angry!'

(7) Jun, ayok cekel sikel wedhuse!

'Jun, let's hold the goat's leg!'

Sentence (5) contains the intention to invite other people to go to the Koran. Sentence (6) contains the intention to invite him to look for something because his father is angry. Sentence (7) contains the intention to invite Jun to hold the leg of the goat.

\section{Forms of Imperative Sentences Containing the Intent of Ordering Repeatedly}

The form of an imperative sentence which contains the intention of telling repeatedly is an imperative sentence which is marked by the presence of a verb marker - no. Example:

(8) Nang endi kakangmu Nto, golekno nopo!

'Where is your brother Nto, find out why!'

Sentence (8) contains the intent to order Anto to find his brother (Anto). The verb marker $-n o$ in the word golekno means to order to find Anto's brother repeatedly.

\section{Forms of Imperative Sentences Containing the Intent to Invite}

The form of an imperative sentence that contains the intention to invite is an imperative sentence which is marked by the presence of the Monggo verb 'Please'. Example:

(9) Monggo dek, manganese ndhisik selak udan Mengko!

'Please honey, eat first before the rain later!

In sentence (9) it contains the intention of inviting younger brother to eat before the rain falls. This is indicated by the presence of the Monggo verb marker 'please'.

\section{Forms of Imperative Sentences Containing Requests}

The form of imperative sentences that contain the intent of a request is an imperative sentence with a verb ending marker - no, the word mbok...-no, tulung...-e . Example:

(10) Aku ngeleh, tukokno panganan! I'm hungry, buy me some food! 
(11) Aku arek mangan, $\underline{\text { mbok } j \text { jikokno }}$ I want to eat, please take it

(12) Mbokmu nang endi, tulung goleke! Where is your mother, please find!

In sentence (10) it contains the intention of asking to buy food because I am hungry. Sentence (11) contains the intention of asking for help to get me food because I am hungry. Sentence (12) contains the intent of a request to find the mother of the speech partner.

\section{Forms of Imperative Sentences Containing Angry Meaning}

The form of an imperative sentence that contains angry intentions is an imperative sentence which is marked by the presence of a verb marker ending in - no. Example:

(13) Guwakno sampahmu iki!

$2323 \#$

'Take away this trash of yours!'

In sentence (13) it contains angry intentions, namely telling the speech partner to throw out the garbage. This is indicated by the presence of a verb ending in $-n o$ in the word guwak 'throw'.

\section{Forms of Imperative Sentences Containing Help}

The form of imperative sentence that contains the meaning of help is an imperative sentence marked by the verb ending - ke and the word tulung 'please'. Example:

(14) Bapakmu arep bali nang omah, tulung guwak sampah iki! 'Your father wants to go home, please throw this garbage away!'

(15) Kok akeh temen yo sampah nang kene, guwakke iki! 'How come there's so much trash here, throw it away!'

In sentence (14) it contains the intention of asking for help to dispose of the garbage there because the father of the speech partner is going home. While sentence (15) contains the intention of asking for help in disposing of garbage because there is a lot of garbage in that place. This is indicated by the presence of the word tulung 'please' and the verb ending - to the word guwak 'waste'.

\section{CONCLUSION}

Based on the discussion in the above can be concluded that the form and intent contained in the Java language imperative sentence ngoko in North Sumatra, namely: First, imperative sentences containing intent sent, sentence type is characterized by a verb suffix $-e$ and no. Second, imperative sentences that contain the intent of prohibition, this type of sentence is marked by the verb ojo 'don't'. Third, imperative sentences that contain the intention of inviting, this type of sentence is marked by the verb Ayo 'mari'. Fourth, imperative sentences that contain the intention of telling repeatedly. This type of sentence is marked by a verb ending in -no. Fifth, imperative sentences that contain the intent to invite, this type of sentence is marked by the verb monggo 'please'. Sixth, imperative sentences that contain the intent of request, this type of sentence is marked by the verb marker ending $-n o$, the word mbok....-no, and tulung...-e. Seventh, imperative sentences containing angry, this type of sentence is marked by the verb ending in $-n$. Eighth, imperative sentences that contain the intention of helping, this type of sentence is marked by the verb ending - $k e$ and the word tulung 'please'. 
Given this research is expected to contribute insight and knowledge to other researchers who want to conduct research that is almost same, imperative sentences in the Java language and Krama Madya, with different dialects

\section{REFERENCES}

Attaskhiiri, Muhammad. (2017). .Analisis Bentuk dan fungsi tutuan ;Impeatif dalam Flim Rafle Kaya Rose Bosch (online) accessed in http://epints.uny.ac.id/46504/.

Hardika Dwi Septian. (2014). An analysis of Imperative Sentences of Iron Man 3 Movie and Their Subtitling. Surakarta: Muhammadiyah University of Surakarta. Published.

Herawati. (2012). Risalah Penelitian: Kalimat Imperatif dalam Bahasa Jawa. Yogyakarta: Balai Bahasa Yogyakarta.

Kesuma, Jati, Mastoyo, Tri. (2007). Pengantar (Metode) Penelitian Bahasa. Jakarta: Carasvatibooks.

Kridalaksana, Harimukti. (1993). Kamus Linguistik (the third edition). Jakarta: Gramedia Pustaka Utama.

Moleong, Lexy J. (2019). Metodologi Penelitian Kualitatif Bandung: Remaja Rosdakarya

Rahardi, Kunjana. (2005). Pragmatik: kesantunan Imperatif Bahasa Indonesia. Jakarta: Erlangga.

Rahmawati, Asrul, N., \& Daulay, I. K. (2021). Diathesis in Mandailing Language South Tapanuli. Randwick International of Education and Linguistics Science Journal, 2(2), 222-227. https://doi.org/10.47175/rielsj.v2i2.264.

Ramaniyar, Eti. 2017. Analisis Tuturan Imperatif Dalam Bahasa Dielek Sintang Kecamatan Serawai Kajian Pragmatik (online). https://journal.ikippgriptk.ac.id/index.php/bahasa/article/view/622.

Sudaryanto, (2015). Metode dan Aneka Teknik Analisis Bahasa.Yogyakarta: Duta Wacana Universitiy Press. 